\title{
Cortisol Binding to Proteins in Plasma in the Human Neonate and Infant
}

\author{
A. J. HADJIAN, M. CHEDIN, C. COCHET, AND E. M. CHAMBAZ(43) \\ Laboratoire d'Hormonologie, Biochimie Médicale, Centre Hospitalier Universitaire de Grenoble, \\ La Tronche, France
}

\section{Extract}

The binding of cortisol to plasma proteins was studied by a methodology allowing the determination of the apparent affinity constant $\left(\mathrm{K}_{\mathrm{a}}\right)$ and the specific binding capacity $\left(\mathrm{N}_{\mathrm{s}}\right)$ for transcortin in different blood compartments in normal pregnant women at term, in the umbilical cord blood, and in normal neonates and infants throughout the first year of life. Removal of endogenous steroids appeared to be necessary for these binding studies, especially in the cord plasma. Both an equilibrium dialysis and an adsorbent technique were used, inasmuch as it has been established that they yield similar results for corticosteroid-binding globulin (CBG) binding parameters.

The high affinity binding of cortisol, attributed to transcortin, was found to have the highest capacity in plasma from pregnant subjects $\left(\mathrm{N}_{\mathrm{s}}=1.16 \pm 0.19 \times 10^{-6} \mathrm{M}\right)$, whereas the fetal compartment (umbilical cord) exhibited low values $\left(0.25 \pm 0.03 \times 10^{-6} \mathrm{M}\right)$. Thus a physiologic barrier to the transplacental passage of transcortin resulted in a large concentration gradient in cortisol-specific binding sites between the fetal and maternal compartments. No significant differences were found for transcortin capacity between venous uterine plasma and peripheral plasma in three subjects studied during cesarean section. A possible physicochemical difference between maternal and fetal transcortin appeared unlikely, because in all blood compartments studied, the apparent affinity constant, $\mathrm{K}_{\mathrm{a}}$, was similar $\left(5-8 \times 10^{8} \mathrm{M}^{-1}\right.$ at $4^{\circ}$ ), and the behavior of the specific cortisol binder in polyacrylamide gel electrophoresis was the same in all cases.

After birth, although the transcortin $\mathrm{K}_{\mathrm{a}}$ for cortisol was still in the same range, $\mathrm{N}_{\mathrm{s}}$ remained low during the first month of life $\left(0.23 \pm 0.07 \times 10^{-6} \mathrm{M}\right)$; after which an increase toward normal adult values was seen, with a rather large variation between individuals from $2-12$ months of age (mean $0.48 \pm$ $\left.0.10 \times 10^{-6} \mathrm{M}\right)$. Children above 1 year exhibited adult values for $\mathrm{N}_{\mathrm{s}}\left(0.51 \pm 0.03 \times 10^{-6} \mathrm{M}\right)$.

\section{Speculation}

From the similarity of values found for transcortin $K_{a}$ and electrophoretic behavior, the physicochemical properties of the glycoprotein cortisol binder are likely to be the same both in the maternal and fetal compartments, although final evidence of chemical identity is not available. Thus, the different binding capacity between these compartments might be attributed to a different concentration in circulating transcortin. This concentration gradient may play a role in the transplacental transfer of corticosteroids during pregnancy and would favor passage toward the maternal compartment. The low transcortin level in the neonatal period might be attributed to a low biosynthesis capacity of the liver in the neonate, although nothing is known about the clearance rate of transcortin in the neonatal period. The transcortin level increases toward adult values during the first year of life and this would suggest either a maturation of the liver biosynthesis enzymatic systems or a biosynthesis stimulation. A possible contribution of a pituitary factor might be suggested on the basis of experimental work in the rat, but the meaning of this increase in cortisol binding capacity in plasma remains to be elucidated.

Limited capacity (specific) high affinity binding of cortisol to transcortin (CBG) in human plasma and other mammalian species is well established; human adult CBG has been isolated by several groups and its physicochemical as well as binding properties have been well described (36). Since then, cortisol binding to plasma proteins has been investigated in normal and various pathologic conditions in the human adult (36). Low values of binding capacity have been reported in human cord plasma $(14,32)$. However, in most of the studies in the human, only the estimation of the binding capacity has been considered. On the other hand, it has been shown that the newborn rat also has a low plasma cortisol binding capacity, rising to the male or female adult values within the first 4-6 weeks of life (36) and that the rhesus monkey shows a progressive increase of plasma cortisol binding capacity after birth until the time of sexual maturation (5).

This work is concerned with the study of the plasma cortisol binding parameters in the human newborn period $\left(\mathrm{K}_{\mathrm{a}}\right.$ and CBG $\mathrm{N}_{\mathrm{s}}$ ), both by equilibrium dialysis and by a more rapid adsorbent technique. The possibility of physicochemical differences between neonatal and adult CBG was examined ( $\mathrm{K}_{\mathrm{a}}$, polyacrylamide gel electrophoresis). In addition, $\mathrm{CBG}$ binding parameters were studied in a number of individual neonates and infants during the first year of life.

\section{EXPERIMENTAL PROCEDURE}

\section{PLASMA SAMPLES}

Fourteen normal adults who were not taking any therapy were studied: 4 adult males and 10 pregnant females at term. Venous blood, $10-20 \mathrm{ml}$, was withdrawn into heparin and immediately centrifuged. The resulting plasma was studied on the same day or kept frozen at $-20^{\circ}$ before processing. In three additional cases, it was possible to obtain blood samples during cesarean section (carried out for obstetrical reasons and resulting in birth of normal infants). In these cases, cortisol binding could be studied in antecubital-peripheral plasma, in 
plasma from the uterine vein obtained by puncture during surgery, before uterostomy, and also from the umbilical cord after its section. Cord plasma was otherwise obtained by collection after vaginal delivery and after section of the umbilical cord; this was a mixture of arterial and venous fetal plasma.

Twenty normal neonates and infants (12 males and 8 females) were studied; all were born at term, after a normal pregnancy terminated by vaginal delivery.

\section{REAGENTS}

Steriods were obtained from Mann Research Laboratory (38); 1,2- $\left[{ }^{3} \mathrm{H}\right]$ cortisol (specific activity $35 \mathrm{Ci} / \mathrm{mmol}$ ) was from New England Nuclear and purified before use by thin layer chromatography $\left(\mathrm{CHCl}_{3}\right.$-methanol, 8:2). Visking tubing $(18 / 32)$ was used for dialysis after extensive washing as described by Westphal (35). Activated charcoal (Norit A) was from Sigma; all other reagents, A grade, were puchased from Prolabo or Merck.

Removal of Endogenous Steroids from Plasma. This was carried out according to the method of Heyns et al. (22) by continuous shaking with activated charcoal $(50 \mathrm{mg} / \mathrm{ml}$ plasma $)$ for $2 \mathrm{hr}$ at room temperature, followed by centrifugation and filtration of the supernatant.

Determination of Plasma Corticosteroids. The assay was carried out by competitive protein binding according to the method of Murphy (28) using dog plasma as the source of binding protein.

Equilibrium Dialysis. This was carried out at $4^{\circ}$ for $48 \mathrm{hr}$ in phosphate buffer, $\mathrm{pH} 7.4,0.155 \mathrm{M}$, according to the method of Westphal (35). The dialysis bags usually received $2 \mathrm{ml}$ $1: 62.5$ diluted plasma. In $10 \mathrm{ml}$ outside buffer, $1: 25 \mu \mathrm{Ci}$ tritiated cortisol and various amounts of cold steroid were dissolved so to achieve 15 different final concentrations of total steroid ranging from $10^{-10}$ to $10^{-7} \mathrm{M}$.

Adsorbent Technique. This technique was also used for the separation of the unbound and bound forms of the steroid after development of the binding equilibrium at $4^{\circ}$. The technique described by Pegg and Keane (29) was followed, the only modification being that instead of Dextran-charcoal, the adsorbent suspension used was made of 1 volume of $1 \%$ Norit $\mathrm{A}+1$ volume of $0.05 \%$ polyvinylpyrrolidone, both in phosphate buffer, $\mathrm{pH} 7.4,0.155 \mathrm{M}$. Each series included duplicate tubes to which buffer was added instead of the charcoal suspension for the counting of the total radioactivity (TR) and three tubes without addition of proteins, for the determination of the nonadsorbed radioactivity (NAR). For each concentration of cortisol, the bound radioactivity $\left(B_{R}\right)$ in the supernatant was measured and the mass of cortisol bound $\left(B_{M}\right)$ calculated according to

$$
B_{M}=\frac{B_{R}-N A R}{T R} \times(M+m+e)
$$

where $\mathrm{M}=$ cold cortisol added; $\mathrm{m}=$ mass of the added tritiated cortisol; $\mathrm{e}=$ mass of the endogenous competing steroid (e was usually neglected since removal of the endogenous steroids was carried out previously).

Polyacrylamide Gel Electrophoresis. Electrophoresis was done in $5 \mathrm{~mm}$ (inner diameter), $8 \mathrm{~cm}$ long Pyrex tubes according to the method of Davis (13). The separation gels were $7.5 \%$ in acrylamide and $0.2 \%$ in bisaurylamide concentrations; stacking gels were $2.5 \%$ in acrylamide and $0.2 \%$ in bisacrylamide concentrations. Bromphenol blue was added to each sample as a tracking dye and to allow the measurement of the $R_{F}$ values for the proteins of interest (12). Staining of control separations was carried out by amido black $10 \mathrm{~B}$.

Labeling of the plasma binding proteins by their radioactive ligand was carried out as follows: the radioactive steroid $(0.1$ $\mu \mathrm{Ci}$ ) was evaporated to dryness and $100 \mu$ I plasma were added.
After $30 \mathrm{~min}$ at $37^{\circ}$, the mixture was incubated for $1 \mathrm{hr}$ at $0^{\circ}$; $100 \mu \mathrm{l} 60 \%$ sucrose solution in the upper electrophoresis buffer, containing bromphenol blue (1\%), were added. Fifty microliters were used immediately for the electrophoresis. After completion of the run, the gels were rapidly cut into 2-mm thick slices.

Liquid Scintillation Counting. Counting was carried out with an Intertechnique SL-30 counter, using the external standarization method. The scintillation mixture was tolueneTriton X-100 (2:1), Permablend II, 5.5 g/liter. This mixture insured an overnight dissolution of the polyacrylamide gel slices.

Results of Binding Experiments. Results were plotted according to the procedure of Scatchard (33) for the determination of $\mathrm{K}_{\mathrm{a}}$ and $\mathrm{N}_{\mathrm{s}}$. Some of the results were represented as Lineweaver-Burk (25) and Baulieu-Raynaud (4) plots, using a manual approach.

\section{RESULTS}

\section{REMOVAL OF PLASMA ENDOGENOUS STEROIDS}

When an untreated umbilical cord plasma was studied, no high affinity binding was obvious on a displacement curve, the radioactive steroid binding being impaired by the presence of large amounts of endogenous steroids and/or possibly other interfering substances (Fig. 1). It was thus necessary to remove this bulk of interfering compounds; the charcoal treatment changed the results drastically and thus rendered possible the study of the present binding systems (Fig. 1). Electrophoresis of plasma before and after charcoal treatment did not show

\section{CORD PLASMA}
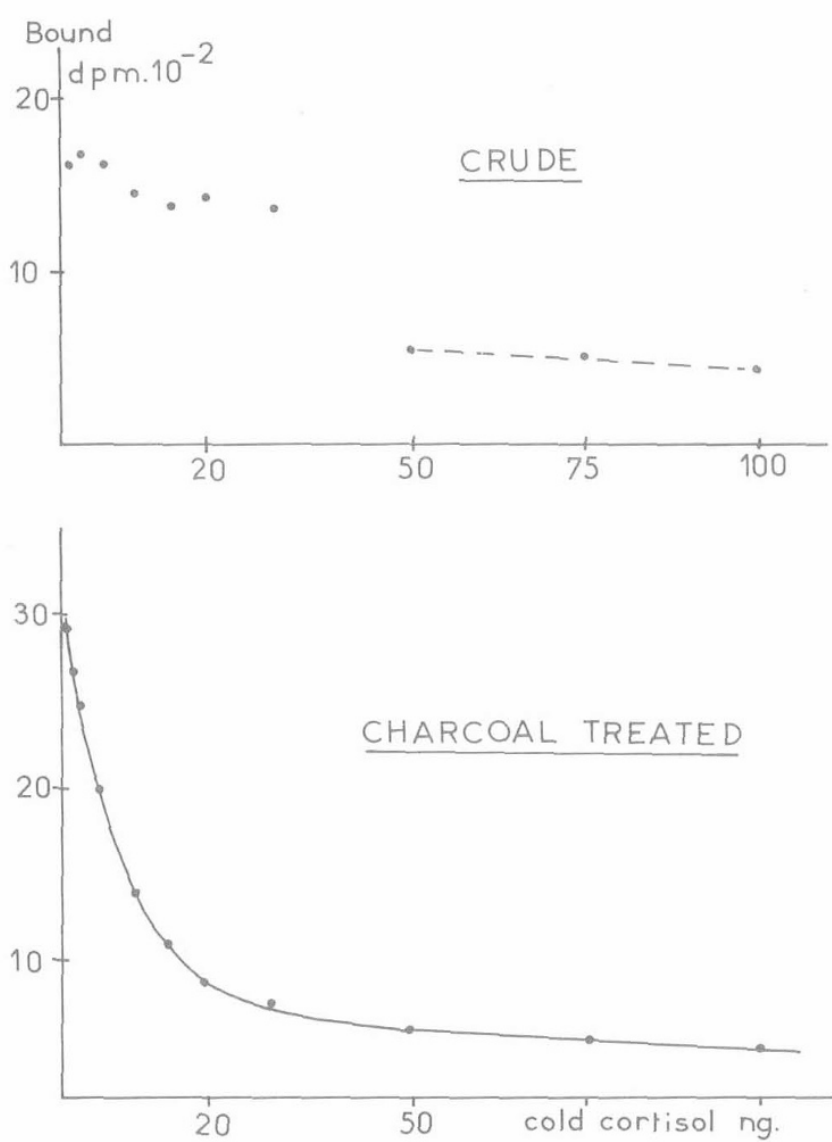

Fig. 1. Cortisol binding and displacement curve under the same conditions (plasma final dilution 1:62.5) for the same plasma before and after charcoal treatment and removal of endogenous binding inhibitors. 
any gross modification of the qualitative and quantitative patterns of protein in plasma. At the same time, however, the concentration of the "total corticosteroids," measured as cortisol by competitive protein binding, dropped drastically from $19 \mu \mathrm{g}$ to $3.1 \mu \mathrm{g} / 100 \mathrm{ml}$ plasma in the example in Figure 1. Heyns et al. (22) reported similar residual values after charcoal treatment of 30 plasma samples $(2.6 \pm 1 \mu \mathrm{g} / 100 \mathrm{ml}$ plasma).

\section{EQUILIBRIUM DIALYSIS VERSUS ADSORBENT METHOD}

The results obtained by the two methods with six different plasmas are reported in Table 1 . The difference between paired results by the two methods was in all cases less than $10 \%$. Despite the fact that the adsorbent techique is not thermodynamically valid since it is a nonequilibrium method, the values obtained for $\mathrm{K}_{\mathrm{a}}$ and $\mathrm{N}_{\mathrm{s}}$ for $\mathrm{CBG}$ were similar with both techniques under the conditions used in this work. As far as the reproducibility of this adsorbent technique is concerned, our results yielded figures similar to the values reported by Pegg and Keane (29) with a variation coefficient of less than $10 \%$.

\section{CBG LEVELS IN FETAL AND MATERNAL} COMPARTMENTS

In three cases, cortisol binding could be studied by equilibrium dialysis at $4^{\circ}$ in cord plasma and in the uterine vein and peripheral plasma from the mother (Table 2). Similar $\mathrm{K}_{\mathrm{a}}$ values were found in all cases $\left(\sim 10^{8} \mathrm{M}^{-1}\right)$, which indicated that a high affinity binder was present in both compartments, with the $\mathrm{K}_{\mathrm{a}}$ expected for the association of cortisol-CBG. $\mathrm{N}_{\mathrm{s}}$ was similar in all of the plasmas of maternal origin, and showed no difference between the peripheral level of CBG and the level in the uterine vein. By contrast, the capacity of the specific binder in cord plasma was four- to fivefold less than in the maternal compartment.

After labeling of the plasma proteins by $\left[{ }^{3} \mathrm{H}\right]$ cortisol, polyacrylamide gel electrophoresis showed, both for maternal and fetal plasma, the presence of the same cortisol-binding material as a well defined radioactive peak with an $R_{F}$ identical in both cases (0.58) (Fig. 2). Furthermore, in both cases, this radioactive peak was diminished and then completely erased by addition of increasing amounts of nonradioactive cortisol, corticosterone, or progesterone.

\section{CORTISOL BINDING IN NEONATE AND INFANT}

The adsorbent method and the calculation using the Scatchard plot were carried out for the determination of the

Table 1. Comparison of results obtained by equilibrium dialysis (ED) and adsorbent technique (AT) for corticosteroid-binding globulin binding capacity $\left(N_{s}\right)$ and apparent association constant $\left(K_{a}\right)$, at $4^{\circ}$, in different human plasma

\begin{tabular}{|c|c|c|c|c|c|}
\hline Plasma source & Technique & $\begin{array}{l}\mathrm{N}_{\mathrm{S}}, \\
\mu \mathrm{M}\end{array}$ & $\begin{array}{l}\text { Differ- } \\
\text { ence, } \%\end{array}$ & $\begin{array}{c}\mathrm{K}_{\mathrm{a}} \\
10^{8} \stackrel{\mathrm{M}}{-1}\end{array}$ & $\begin{array}{l}\text { Differ- } \\
\text { ence, \% }\end{array}$ \\
\hline $\begin{array}{l}\text { Normal neonate } \\
\text { (8 days) }\end{array}$ & $\begin{array}{l}\text { ED } \\
\text { AT }\end{array}$ & $\left.\begin{array}{l}0.26 \\
0.25\end{array}\right\}$ & 4.6 & $\left.\begin{array}{l}8.7 \\
8.6\end{array}\right\}$ & 1.1 \\
\hline $\begin{array}{l}\text { Normal infant } \\
(4 \mathrm{mo})\end{array}$ & $\begin{array}{l}\text { ED } \\
\text { AT }\end{array}$ & $\left.\begin{array}{l}0.40 \\
0.41\end{array}\right\}$ & 3.1 & $\left.\begin{array}{l}7.2 \\
6.5\end{array}\right\}$ & 8.9 \\
\hline Normal adult male & $\begin{array}{l}\text { ED } \\
\text { AT }\end{array}$ & $\left.\begin{array}{l}0.46 \\
0.48\end{array}\right\}$ & 4.6 & $\left.\begin{array}{l}5.0 \\
4.8\end{array}\right\}$ & 3.2 \\
\hline $\begin{array}{l}\text { Normal pregnancy } \\
\text { (term) }\end{array}$ & $\begin{array}{l}\text { ED } \\
\text { AT }\end{array}$ & $\left.\begin{array}{l}1.38 \\
1.25\end{array}\right\}$ & 9.6 & $\left.\begin{array}{l}5.0 \\
4.5\end{array}\right\}$ & 10.0 \\
\hline $\begin{array}{l}\text { Normal pregnancy } \\
\text { (term) }\end{array}$ & $\begin{array}{l}\text { ED } \\
\text { AT }\end{array}$ & $\left.\begin{array}{l}1.22 \\
1.33\end{array}\right\}$ & 8.1 & $\left.\begin{array}{l}13.3 \\
14.5\end{array}\right\}$ & 8.4 \\
\hline $\begin{array}{l}\text { Normal pregnancy } \\
\text { (term) }\end{array}$ & $\begin{array}{l}\text { ED } \\
\text { AT }\end{array}$ & $\left.\begin{array}{l}1.10 \\
1.12\end{array}\right\}$ & 2.2 & $\left.\begin{array}{l}7.9 \\
8.4\end{array}\right\}$ & 10.2 \\
\hline Mean \pm SD & $5.3 \pm 2.6$ & 6.9 & \pm 3.5 & & \\
\hline
\end{tabular}

Table 2. Corticosteroid-binding globulin binding parameters for cortisol, in different fetal and maternal compartments (equilibrium dialysis, $\left.4^{\circ}\right)^{1}$

\begin{tabular}{|c|c|c|c|c|c|c|c|c|}
\hline Plasma source & $\mathrm{N}_{\mathrm{s}_{1}}{ }^{2}$ & $\mathrm{~K}_{\mathrm{a}_{1}}{ }^{3}$ & $\mathrm{~N}_{\mathrm{s}_{2}}$ & $\mathrm{~K}_{\mathrm{a}_{2}}$ & $\mathrm{~N}_{\mathrm{s}_{3}}$ & $\mathrm{~K}_{\mathrm{a}_{3}}$ & $\begin{array}{l}\mathrm{N}_{\mathrm{s}} \\
\text { (mean } \\
\pm 1 \mathrm{SD} \text { ) }\end{array}$ & $\begin{array}{c}\mathrm{K}_{\mathrm{a}} \\
(\text { mean } \\
\pm 1 \mathrm{SD})\end{array}$ \\
\hline $\begin{array}{l}\text { Maternal } \\
\text { peripheral } \\
\text { vein }\end{array}$ & 1.13 & 6.9 & 1.25 & 4.9 & 1.33 & 6.0 & $\begin{array}{r}1.24 \\
\pm 0.09\end{array}$ & $\begin{array}{r}5.93 \\
\pm 0.82\end{array}$ \\
\hline Uterine vein & 1.22 & 5.2 & 1.07 & 9.9 & 1.29 & 5.5 & $\begin{array}{r}1.20 \\
\pm 0.09\end{array}$ & $\begin{array}{r}6.86 \\
\pm 2.15\end{array}$ \\
\hline Umbilical cord & 0.29 & 4.3 & 0.22 & 5.3 & 0.25 & 5.7 & $\begin{array}{r}0.25 \\
\pm 0.03\end{array}$ & $\begin{array}{r}5.10 \\
\pm 0.59\end{array}$ \\
\hline
\end{tabular}

${ }^{1}$ Numeral with $\mathrm{N}_{\mathrm{S}}$ and $\mathrm{K}_{\mathrm{a}}$ indicates three different pregnant subjects.

${ }^{2}$ Binding capacity, micromoles of cortisol per liter of plasma.

${ }^{3}$ Apparent association constant, $10^{8} \mathrm{M}^{-1}$.

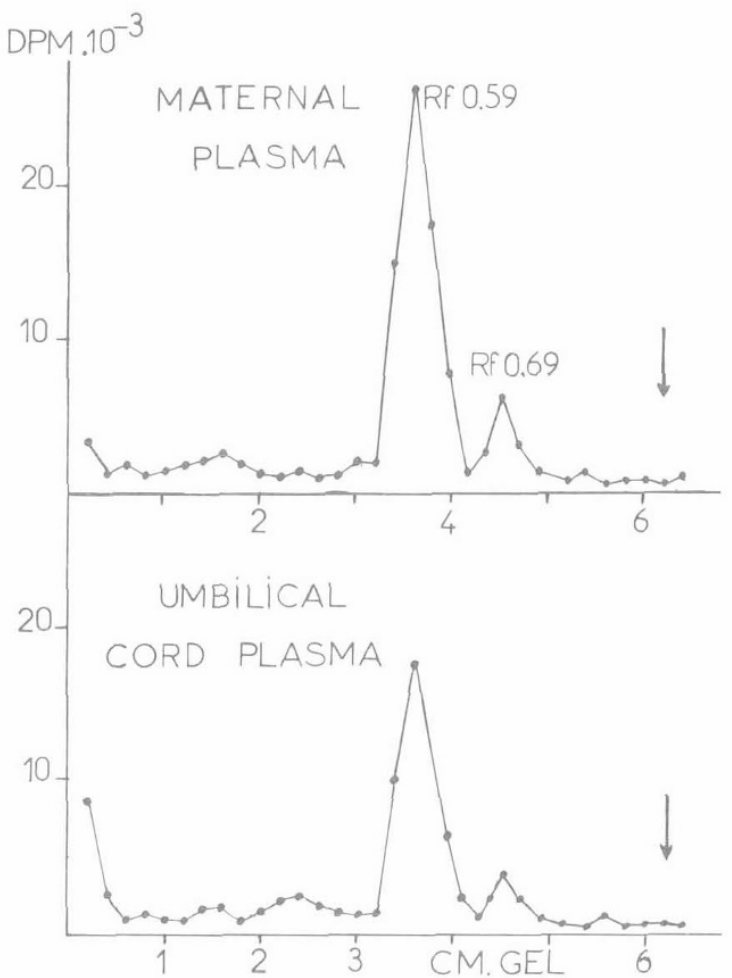

Fig. 2. Polyacrylamide gel electrophoresis of maternal and cord plasma after labe, $n$ n with tritiated cortisol. Plotting of the radioactivity along the gel after the electrophoretic separation showed in both cases a major peak of the same mobility $\left(\mathrm{R}_{\mathrm{F}} 0.58\right)$ attributed to plasma corticosteroid-binding globulin (CBG). The small peak $\left(\mathrm{R}_{\mathrm{F}} 0.69\right)$ had the electrophoretic mobility of human serum albumin. The CBG peak was suppressed by addition of $10^{-6} \mathrm{M}$ of unlabeled cortisol. $\mathrm{R}_{\mathrm{F}}$ values were measured by reference to the band given by the bromphenol blue, which was used as the tracking dye.

CBG binding parameters $\left(\mathrm{K}_{\mathrm{a}}, \mathrm{N}_{\mathrm{s}}\right)$ in plasma from different normal neonates and infants. To compare our results with values reported previously by other workers using various experimental methods, four normal adult males were studied.

The average values obtained were $5.7 \times 10^{8} \mathrm{M}^{-1}$ for $\mathrm{K}_{\mathrm{a}}$ and $0.50 \pm 0.03 \times 10^{-6} \mathrm{M}$ for $\mathrm{N}_{\mathrm{s}}$ (Table 3 ):

Ten normal pregnant women at term gave average values $\left(1.16 \pm 0.19 \times 10^{-6} \mathrm{M}\right.$ for $\mathrm{N}_{\mathrm{s}}$ and $8.2 \pm 3 \times 10^{8} \mathrm{M}^{-1}$ for $\left.\mathrm{K}_{\mathrm{a}}\right)$, also in agreement with previously established data.

By contrast, the values found for the umbilical cord plasma studied were similar to the adult values with regard to the 
apparent affinity constant $\left(5.1 \pm 0.6 \times 10^{8} \mathrm{M}^{-1}\right)$, but the binding capacity was half that of the normal male adult $\left(0.25 \pm 0.03 \times 10^{-6} \mathrm{M}\right)$, confirming the previous findings by De Moor (14) and Sandberg (32).

The binding capacity remained low during the first month of life, the average value being $0.23( \pm 0.07) \mu \mathrm{M}$. A rise of this value toward adult level was seen in the following months of life (Table 3), and, after 1 year of age, all of the children studied exhibited adult values for $\mathrm{N}_{\mathrm{s}}$ as well as for $\mathrm{K}_{\mathrm{a}}$. Thus, the neonatal low plasma CBG concentration appeared to increase slowly toward the adult level.

However, the variations within individuals appeared rather large in this process and the average value obtained from $2-12$ months of age was similar to the adult figure ( 0.48 versus 0.50 $\mu \mathrm{M})$, the standard deviation being much larger $(0.10$ versus $0.03)$. However, all values above 2 years of age are in the adult range (Table 3 ).

\section{DISCUSSION}

Equilibrium dialysis is the thermodynamically valid method of choice for steroid binding study (see Reference 36 for references). Several problems are encountered in the use of adsorbents and have recently been throughly investigated in the case of dextran-coated charcoal suspension (9). Pegg and Keane (29) have already introduced a dextran-charcoal technique for the determination of the CBG binding parameters in human adult plasma with satisfactory results. Our data obtained on the same samples by parallel equilibrium dialysis and the adsorbent technique showed that indeed the adsorbent method, although not valid for thermodynamic studies, was useful for comparative studies of binding properties in well defined biologic mixtures.

A Scatchard plot was used in all cases for the CBG $\mathrm{K}_{\mathrm{a}}$ and $\mathrm{N}_{\mathrm{s}}$ evaluations (Fig. 3). Typically, two straight lines could be quite easily defined and the steepest one was used for the estimation of the CBG binding parameters. Several procedures have been proposed for a more accurate graphic evaluation of the specific system when it is present together with a nonspecific, high capacity one $(19,30)$. However, in our case, two binding systems were well defined and a graphic construction according to the method of Rosenthal (30) brought only negligible differences in the results for $\mathrm{K}_{\mathrm{a}}$. In a few cases, other types of graphic representations were used. The reciprocal plot (25) and the proportional graph (4) yielded very similar results from the same experimental data (Fig. 3).

The "specific" cortisol binding moiety present in the neonatal plasma had a similar affinity constant and the same mobility on polyacrylamide gel electrophoresis as the adult CBG and, to our knowledge, no difference in physicochemical properties between adult and neonatal CBG has been reported. On the other hand, the presence of competitive inhibitors in the neonatal plasma which were not removed by the charcoal treatment would alter CBG $\mathrm{K}$ but not $\mathrm{N}_{\mathrm{s}}$ values. Other types of inhibitors might explain this low $\mathrm{N}_{\mathrm{s}}$ with normal $\mathrm{K}_{\mathrm{a}}$, but the more likely explanation is that of a low circulating CBG level. By contrast to the elevated level in the maternal compartment, this low level on the fetal side raises several problems, as follows.

\section{CORTISOL TRANSPLACENTAL TRANSFER NEAR TERM}

Cortisol exchange between the maternal and fetal compartments has been demonstrated in both directions $(6,26)$ with an apparent predominance from fetus to mother $(2,3,27)$. The existence of a placental diffusion barrier has been documented in animal experiments $(7,15)$. Our studies were carried out at birth and our results may reflect the fetal situation near term. There are some major differences between the fetal and maternal vascular compartments, as far as specific cortisol binding is concerned. On the maternal side, the CBG
Table 3. Binding capacity

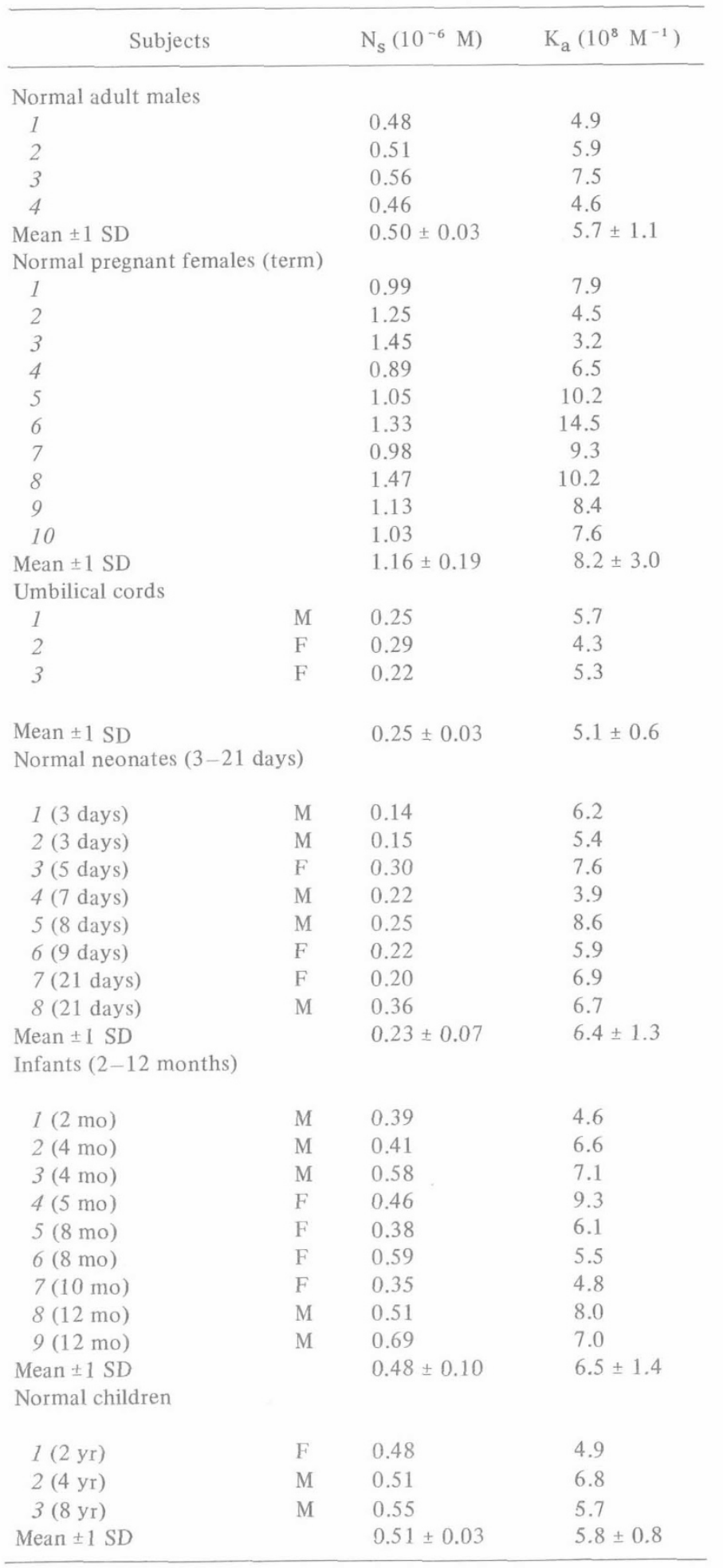

binding capacity is elevated and it has been estimated that 55 to $60 \%$ of the specific binding sites could remain free $(10,31)$. By contrast, the fetal plasma exhibits low specific binding capacity for cortisol and in addition contains high levels of competing steroids, able to bind to the same sites. For example, $50 \%$ of the placental progesterone production goes to the fetus (37), and this steroid has a high affinity for CBG at $37^{\circ}(16,34)$. This situation would result in a relatively large proportion of unbound plasma cortisol in the fetal plasma. The maternal over fetal total plasma cortisol ratio has been evaluated as $3: 1$, whereas the ratio for the unbound hormone was found to be $1: 1$ (1). This unbound form may represent the fraction of the hormone exchangeable through the 

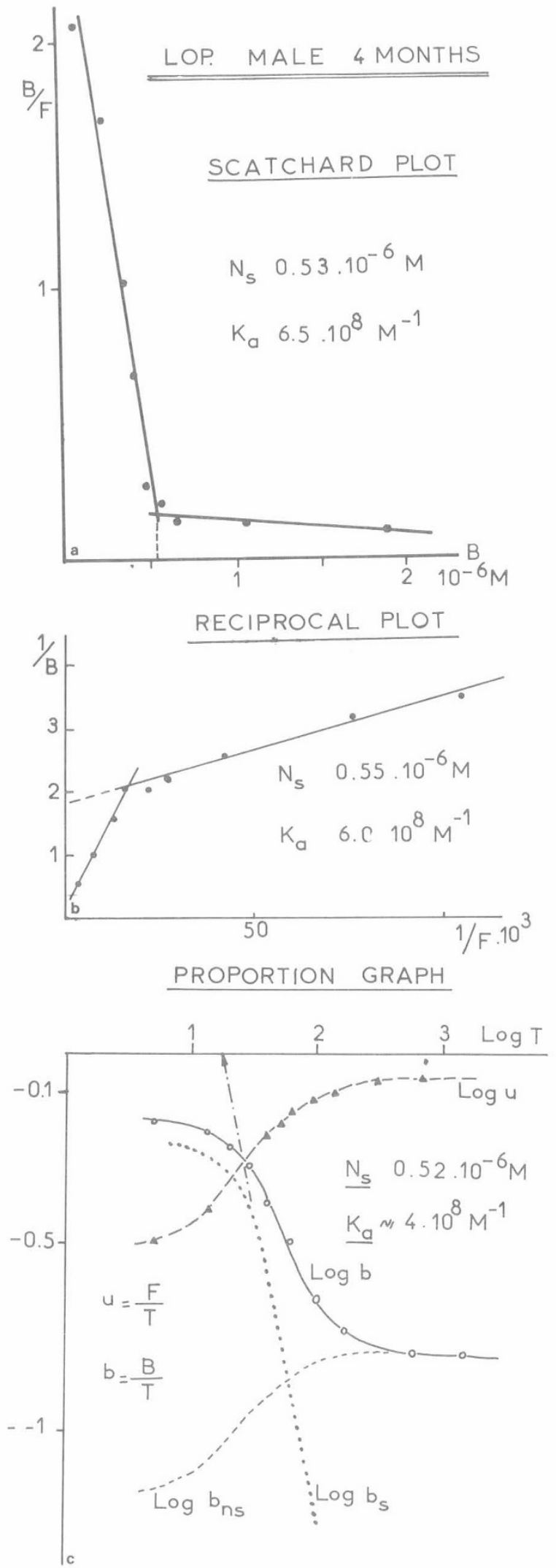

Fig. 3. Typical graphic representations obtained from the same binding data for plasma from a 4-month-old male infant. The Scatchard plot $(a)$, the Lineweaver-Burk plot $(b)$, and the proportion graph $(c)$ yielded essentially similar results for specific binding capacity $\left(N_{s}\right)$ and apparent association constant $\left(K_{a}\right) . B$ and $F$ represent, respectively, the concentration of bound and unbound steroid; $T$ is the total concentration of the steroid present and was used in the proportion graph as described by Baulieu and Raynaud (4). placental barrier and the available binding sites on the maternal side might contribute to favor the steroid transfer in this direction.

\section{CORTISOL METABOLISM IN PERINATAL PERIOD}

After birth, the plasma concentration of steroids of extrafetal origin decreases rapidly, as seen, for instance, with progesterone (11). Neonatal cortisol level in plasma is relatively low $(23,24)$ and in agreement with the available specific binding capacity given by our data. In fact, the neonatal cortisol half-life is not shorter than in the adult but, on the contrary, rather elevated for large doses $(1,8)$. These facts cannot be clearly related to the observed increase in plasma CBG during the first year of life and the role (if any) of the increase in plasma cortisol binding sites during this period remains to be elucidated.

\section{EVOLUTION OF CBG LEVEL AFTER BIRTH}

CBG synthesis is generally considered to take place in the liver (36). The effect of estrogens on plasma CBG level is well documented, and is believed to reflect increased hepatic CBG biosynthesis $(17,18,20-22)$. On the basis of experiments in the rat $(17,18,36)$, a release of thyrotropic hormone has been suggested to explain this estrogen effect. To our knowledge, there is no evidence to support the participation of a pituitary factor in the regulation of CBG level in the human. Recently, Beamer et al. (5) studied plasma cortisol binding in rhesus monkeys from birth to adulthood and also found low levels in the neonatal period with a progressive increase toward adult values within the first 2 years of life. The time at which adult CBG level was reached coincided with the development of sexual maturity. This is in contrast to our results in the human showing that adult CBG levels are reached much earlier.

The CBG present in the fetal compartment can be supposed to be of fetal origin. However, the time at which the human fetus might be able to carry out the biosynthesis of this glycoprotein is not known. A contribution of the maternal compartment or a possible CBG-like macromolecule of placental origin is purely hypothetical.

\section{REFERENCES AND NOTES}

1. Aarskog, D.: Cortisol in the newborn infant. Norwegian monographs on Medical Science, p. 13 (Scandinavian University Books, 1964).

2. Abramovich, D. R, and Wade, A. P.: Transplacental passage of steroids: The presence of corticosteroids in amniotic fluid. J. Obstet. Gynaec. Brit. Commun., 76: 610 (1969).

3. Abramovich, D. R., and Wade, A. P.: Levels and significance of 17 oxosteroids and 17 hydroxycorticosteroids in amniotic fluid throughout pregnancy. J. Obstet. Gynaec. Brit. Commun., 76: 893 (1969).

4. Baulieu, E, E., and Raynaud, J. P.: A "proportion graph" method for measuring binding systems. Eur. J. Biochem., 13: 293 (1970).

5. Beamer, N., Hagemenas, F. C., and Kittinger, G. W.: Development of cortisol binding in the rhesus monkey. Endocrinology, 93: 363 (1973).

6. Beitins, J. Z., Bayard, F., Ances, I. G., Kowarski, A., and Migeon, C. J.: The metabolic clearance rate, blood production, interconversion and transplacental passage of cortisol and cortisone in pregnancy near term. Pediat. Res., 7: 509 (1973)

7. Beitins, J. Z., Kowarski, A., Shermeta, D. W., Delemos, R. A., and Migeon, C. J.: Fetal and maternal secretion rate of cortisol in sheep: Diffusion resistance of the placenta. Pediat. Res., 4: 129 (1970).

8. Bertrand, J., Loras, B., Gilly, R., and Cautenet, B.: Contribution à l'étude de la sécrétion et du métabolisme du cortisol chez le nouveau-né et le nourrisson de moins de trois mois. Pathol. Biol. Paris, 11: 997 (1963).

9. Binoux, M. A., and Odell, W. D.: Use of dextran coated charcoal to separate antibody bound from free hormone. J. Clin. Endocrinol. Metab., 36: 303 (1973)

10. Booth, M., Dixon, P. F., Gray, C. H., Greenaway, J. M., and Holness, N. J.: Protein binding of cortisol in health and in pregnancy. J. Endocrinol., 23: 25 (1961). 
11. Conly, P. W., Morrison, T., Sandberg, T. H., and Cleveland, W. W. Concentration of progesterone in the plasma of mothers and infants at time of birth. Pediat. Res., 4: 76 (1970).

12. Corvol, P. L., Chrambach, A., Rodbard, D., and Bardin, C. W.: Physical properties and binding capacity of testosterone-estradiol binding globulin in human plasma, determined by polyacryl amide gel electrophoresis. J. Biol. Chem., 246: 3435 (1971).

13. Davis, B. J.: Disc electrophoresis. II. Method and application to human serum proteins. Ann. N. Y. Acad. Sci., 121: 404 (1964).

14. De Moor, P., Heirwegh, K., Heremans, J., and Declerck-Raskin, M.: Protein binding of corticoids studied by gel filtration. J. Clin. Invest., 41: 816 (1962).

15. Dixon, R., Hyman, A. Gurpide, E, Dyrenfurth, J., Cohen, H. Bowe, E., Engel, T., Daniel, S., James, S., and Vande Wiele, R. Fetomaternal transfer and production of cortisol in the sheep. Steroids, 16: 771 (1970).

16. Doe, R. P., and Seal, U. S.: Protein binding of cortisol in man. J. Clin. Invest., 42: 929 (1963).

17. Gala, R. R., and Westphal, U.: Corticosteroid binding globulin in the rat: Studies on the sex difference. Endocrinology, 77: 841 (1965).

18. Gala, R. R., and Westphal, U.: Further studies on the corticosteroid binding globulin in the rat: Proposed endocrine control. Endocrinology, 79: 67 (1966).

19. Goldie, D. J., Hasham, N., Keane, P. M., and Walker, W. H. C.: Temperature dependence of cortisol binding to plasma proteins. Nature, 217: 852 (1968).

20. Guidollet, J., and Louisot, P.: Rôle de l'oestradiol et de la thyroxine dans l'augmentation du nombre de sites subcellulaires fixateurs d'hormones corticostéroides en l'absence de biosynthèse glycoprotéinique. C.-R. Acad. Sci. Ser. D, 269: 659 (1969).

21. Guidollet, J., and Louisot, P.: Biosynthèse de la transcortine II Rôle des oestrogènes dans l'activation des sites moléculaires préalablement marqués. Acta Endocrinol., 62: 468 (1969).

22. Heyns, W., Van Baelen, H., and De Moor, P.: Study of steroid protein binding by means of competitive adsorption: Application to cortisol binding in plasma. Clin. Chim. Acta, 18: 361 (1967).

23. Hillman, D. A., and Giroud, C. J. P.: Plasma cortisol and cortisone levels at birth and during the neonatal period. J. Clin. Endocrinol. Metab., 25: 243 (1965).

24. Iturzaeta, N. F., Hillman, D. A., and Colle, E.: Measurement of plasma cortisol in children and adults: A comparison of the double isotope derivative assay, competitive protein binding and the modified competitive protein binding analysis. J. Clin. Endocrinol. Metab., 30: 185 (1970).

25. Klotz, I. M.: Protein interaction. In E. Neurath and K. Bailey: The Proteins, Vol. 1B, p. 727 (Academic Press, New York, 1953).

26. Migeon, C. J., Bertrand, J., and Gemzell, C. A.: The transplacental passage of various steroid hormones at midpregnancy. Recent Progr. Hormone Res., 17: 207 (1961).

Copyright (c) 1975 International Pediatric Research Foundation. Inc.
27. Migeon, C. J., Bertrand, J., and Wall, P. E.: Physiologic disposition of $4-\mathrm{C}^{14}$ cortisol during late pregnancy. J. Clin. Invest., 36: 1350 (1957).

28. Murphy, B. E. P.: Some studies of the protein binding of steroids and their application to the routine micro and ultramicro measurement of various steroid in body fluids by competitive protein binding radioassay. J. Clin. Endocrinol. Metab., 27: 973 (1967).

29. Pegg, P. J., and Keane, P. M.: The simultaneous estimation of plasma cortisol and transcortin binding characteristics by a competitive protein technique. Steroids, 14: 705 (1969).

30. Rosenthal, H. E.: A graphic method for the determination and presentation of binding parameters in a complex system. Anal. Biochem., 20: 525 (1967).

31. Rosenthal, H. E., Slaunwhite, W. R., and Sandberg, A. A. Transcortin: A corticosteroid binding protein of plasma. X. Cortisol and progesterone interplay and unbound levels of these steroids in pregnancy. J. Clin. Endocrinol. Metab., 29: 352 (1969).

32. Sandberg, A. A., and Slaunwhite, W. R., Jr.: Transcortin: A corticosteroid binding protein of plasma. II. Levels in various conditions and the effects of estrogens. J. Clin. Invest., 38: 1290 (1959).

33. Scatchard, G.: The attractions of proteins for small molecules and ions. Ann. N. Y. Acad. Sci., 51: 660 (1949).

34. Seal, U. S., and Doe, R. P.: Corticosteroid binding globulin: biochemistry, physiology and phylogeny. In: G. Pinkus, T. Nakao, and J. F. Tait: Steroid Dynamics, p. 63 (Academic Press, New York, 1966).

35. Westphal, U.: Assay and properties of corticosteroid binding globulin and other steroid binding serum proteins. Methods Enzymol., 15: 761 (1969).

36. Westphal, U.: Steroid protein interactions. Monographs in Endocrinology (Springer Verlag, New York, 1971).

37. Zander, J., Holzmann, K., and Bengtsson, L. P.: Progesterone metabolism in an anencephalic newborn. Acta Obstet. Gynecol. Scand., 44: 204 (1965).

38. New York, N. Y.

39. Frankfurt, Germany.

40. St. Louis, Mo.

41. We are indebted to Dr. P. Leger, Dr. Ben Bassa, and Dr. Guignier for providing blood samples.

42. This work was made possible by the financial support from the Délégation Générale a la Recherche Scientifique et Technique, the Institut National de la Santé et de la Recherche Médicale, and the Fondation pour la Recherche Médicaie Française.

43. Requests for reprints should be addressed to: E. M. Chambaz, M.D., Laboratoire d'Hormonologie, Biochimie Médicale, Centre Hospitalier Universitaire de Grenoble, La Tronche, France.

44. Accepted for publication July 30, 1974. 